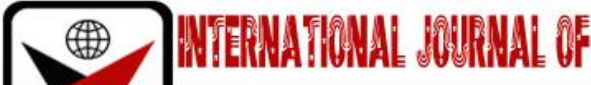

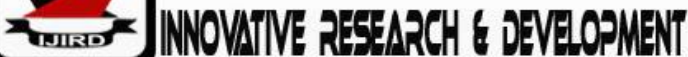

ISSN 2278 - 0211 (Online)

\section{Relationship between Policy and Politics: Evaluation of Agricultural Policy in Nigeria}

\author{
Ughulu, Eghoikhunu Stella \\ Ph.D. Student, Department of Political Science and Public Administration, \\ Igbinedion University, Okada, Edo State, Nigeria \\ Nwokike, Eunice Ijeaku \\ Deputy Registrar, Department of Political Science and Public Administration, \\ School of Post Graduate Studies, Benson Idahosa University, Benin City, Edo State, Nigeria
}

\begin{abstract}
:
For a long time, there has been the debate among scholars of the presence or absence of a relationship between politics and policy. Thus, this study examined whether or not there is a relationship between politics and policy through the policy process of agricultural sector in Nigeria. The study examined the different definitions of politics and policy/public policy expressing the importance of one to the other. The study also examined the Nigeria agricultural policy and its institutional framework and examined the interplay between politics and policy in the agricultural policy process formulation. The study utilized the secondary method of data collection. The various actors and their contributions to policy process in agricultural sector of Nigeria have been used to show the way and manner in which politics is an indispensable part of policy process. This paper, therefore, concluded that there is always interaction between politics and public policy at every stage of policy process, resulting in a close relationship which makes it rather difficult to divorce one from the other.
\end{abstract}

Keywords: Politics, Policy, Agricultural Policy

\section{Introduction}

Some scholars of public administration have argued that politics should be separated from administration while others have argued in the opposite direction claiming that there can be no separation between politics and administration and that public administration is policy making and thus a political process. The above argument has been on for ages; in response, this study examined the relationship between politics and policy. This study substituted policy for administration since it is an integral part of administration and it also attempted to show the relationship between politics and policy by discussing it from the perspective of politics and policy process, drawing examples from the Nigerian agricultural policy.

The main objective of the study is to examine the relationship between politics and policy from the Nigerian agricultural policy, other objectives are the make the reader understand the concept of politics and policy; examine politics/administration (policy) dichotomy and examine the policy in Nigeria agricultural policy.

In achieving the above objectives, the following questions are asked?

- What is politics and policy?

- What is the politics/administration (policy) dichotomy?

- What is Nigerian agricultural policy and the institutional frameworks

- What is the relationship between politics and policy in Nigeria agricultural policy process?

The study relied on secondary data (existing literatures) as source of data. Books, journals, articles, newspapers, internet and government publications on the subject matter were consulted.

\section{Conceptualization of Policy/Public Policy}

According to Dye, T. (1975), 'public policy is whatever governments choose to do or not to do'. While Eyestone, R. (1971) defines public policy broadly as 'the relationship of government unit to its environment'. According to Anderson, J. (1975) 'public policy is a purposive course of action followed by an actor or a set of actors in dealing with a problem or matter of (social) concern'. Similarly, Ikelegbe A.0. (2006) defined public policy as 'An integral programme of actions which an actor (or a group of actors) is accustomed to or intends to undertake in response to given problems or situations with which he is confronted'.

Decision is distinguished from policy because it is not in all cases that decisions become policies, even though there cannot be a policy without a decision. This agrees with the view of Adamolekun, L. (1983) which states that 'policy is 
a course setting involving decisions of widest ramifications and longest-term perspective in the life of an organization but which are more involving than ordinary decisions'.

Policy/public policy is conceptualized in this work as a final decision or plan made by government, after reviewing several available options, towards the achievement of set objectives. In this study, policy is viewed from the public perspective and as such policy is referred to as the actions of government directed at achieving certain goals.

Public policies are usually expressed in legislative enactments, laws, executive decrees or orders, executive and official statements or speeches, government budgets, judicial decisions and, sometimes, political party manifestoes (Ikelegbe, 2006). A policy is meant to address particular needs of the citizens made known through what is called policy demands (Makinde, 2013). From the above submissions on public policy, it is evidenced that policy making is impossible without human interactions. From the identified problem to be solved through formulation and implementation of policy, human interactions are involved. Thus, a policy can be conceptualized as a government's plan that is put in place, after considering various alternatives, as a response to the demands of the society in different areas such as the economy, education, health, gender, security, and involves expenditure of public resources and the use of coercion, where necessary, to achieve the set objectives.

\section{Conceptualization of Politics}

Politics is a discipline of social science that involves the resolution of conflicts and the activity of government. Politics is also the authoritative allocation of values such as making decision on who gets what, how and when. Lasswell, D. (1936) conceives politics as who gets what, when, and how? Similarly, Easton, D. (1965), views politics from the perspective of the process of authoritative allocation of scarce values which may be in the form of services, goods and money, or in terms of the formulation of policies on different areas of governance such as health, education, and security, among others. According to Lasswell, D. and Kaplan, A. (1950) politics is the process of making and executing governmental decisions or policies'. Khan, H. (1997) views politics as activities revolving around the decision-making organs of the state which involves the concepts of power, authority, command, and control. Some scholars attempt to define politics in terms of conflict resolution - According to Awopeju. A. (2010) 'whenever we have more than one man, there is politics because politics can be found in a church, in a family, in a trade union, school, community, and state, among others. Kolawole, D. (1997) defines politics as 'the aggregation of the inter-relationship of man, his environment and the management of any conflict arising from such association'. Igho, 0. (2006) also sees politics as the formulation and management of policies.

From the above definitions; this study will conceptualize politics as the activities of government in resolving conflicts arising from the competition for societal values by the people in the state, as well as allocating resources through various decisions resulting in the formulation of policies.

\section{The Politics/Administration Dichotomy}

A discussion on politics/administration (policy) is necessary at this point to show that politics cannot be separated from policy which falls under the umbrella of administration.

The relationship between politics and administration has evolved over the years till date. It has been the subject of debate among scholars, administrators, politicians and others. Early scholars have observed the differentiation between policy matters and administrative matters leading to a dichotomy between politics and administration. Although this idea has been abandoned after the Second World War, yet this ancient administrative proverb that politics and administration are separate enterprises continues to be debated. Guy, P.B. (1984), remarks, 'Although any number of authors have attempted to lay this proverb to rest, it has displayed amazing powers of survival and reappears in any number of setting in any number of political system'.

It was Woodrow Wilson, a statesman, politician, scholar and administrator who first made a distinction between politics and administration in the 1880s in his paper 'The Study of Administration', which was published in 1887, that formally launched the subject of administration distinct from politics. To quote his words: '... that administration lies outside the proper sphere of politics. Administrative questions are not political questions. Although politics sets the tasks for administration, it should not be suffered to manipulate its offices. The field of administration is a field of business. It is removed from the hurry and strife of politics: it at most points stands apart even from the debatable ground of constitutional study. It is a part of political life only as the methods of the counting house are a part of the life of society; only as a machinery is part of the manufactured product. But it is at the same time raised very far above the dull level of mere technical detail by the fact that through its greater principles it is directly connected with the lasting maxims of political wisdom, the permanent truths of political progress' (Woodrow W., 1941).

Other scholars who supported Woodrow's politics/administration dichotomy theory are Frank Goodnow, and W.F. Willoughby. Frank Good now in his politics and administration, (1900), where he made a distinction between politics and administration and also viewed politics as 'the expression of the will of the state', and administration as 'the execution of that will'. Similarly, Lepawsky, A. (1970) remarked that Willoughby tried to give an even more separate status to administration not merely by marking it off from politics, but by setting it up as a fourth branch of government, along with legislature, executive and judiciary. He confined the use of the word administration to the operations of the administrative branch only. He even differentiated between executive power and administrative power. Lepawsky, A. (1970) remarks that 'Willoughby's recognition of administration as a fourth branch of government is the most extreme but probably the most logical result of the strict separation of administration and politics initiated by Woodrow.

However, some scholars were not in support of the above position. It was argued that the non-political view of public administration as propounded by the $19^{\text {th }}$ century thinkers was not valid in the present set up of government. 
Public administration is a part of the political process. In various ways such as helping to shape legislation, dealing with pressure groups and other agencies etc., the administrators act politically. It is further emphasized that the chief executive is not only the chief administrator but also the chief political officer of the nation. It is through the chief executive, as the principal means that the politically mobilized electorate makes bureaucracy the vehicle of its aspirations and wishes. Therefore 'all administration and all policy making in government are political' (Mohd A.A.K., 1983).

Several scholars lent support to this view - Paul Appleby, Dwight Waldo, F.M. Max, V.O. Key and M.D. Dimock (all cited in Polinaidu, 2004), all rejected the separation of politics from administration in favour of the fusing of politics and administration. In his book titled Policy and Administration 1949, Appleby writes that 'public administration is policymaking and part of political process. Dimock, on his part, states that 'politics runs all the way through administration'. While Fred W. Riggs says that bureaucrats perform both administrative and political functions, especially in developing countries (cited in Polinaidu, 2004). The young Minnobrook scholars, according to Polinaidu, who happen to be new scholars of new public administration, also believe that administrators do make policies and should make them. The public choice theory and public management have also clearly shown that the founding father's (Woodrow's) doctrine of politics/administration dichotomy is not relevant today. They brought into focus the emerging trend towards the integration of administration and politics. Dwight Waldo concluded that the separation between politics and administration had become an 'outworn credo' (Lepawsky A. 1970).

As work load of government increased, by necessity more and more decisions were made outside the political branches of government and in the administrative branches. 'It became increasingly apparent that government decisions were not all made in the hallowed halls of the legislature, rather a good number of them were made in the less impressive but more numerous halls of administrative office buildings' (Guy, B.P., 1984).

The above discussion clearly shows that there is a strong relationship between politics and public policies and as such cannot be separated. Let us be reminded that politics is defined as the authoritative allocation of resources, such as making decision on who gets what. Policy, on its part, is defined as what government chooses to do or not to do.

\section{Policy Process in Agricultural Policies in Nigeria: Relationship between Policy and Politics}

Policy process refers to how policies come about, what is involved from problem identification to policy formulation, implementation and evaluation. According to Robinson, J. A. and Majak, R. R., (1967), it refers to the methods, conditions, procedures, structures, resources, activities, interactions and stages by which policies are made, implemented and impacts on the political system and its environments

Policy From the conceptualization of policy in this study above, agricultural policy is defined as the final decision or plan made by government, after reviewing several available options, towards the achievement of set objectives in the agricultural sector. Agricultural policy is a statement of action and a fundamental tool employed in achieving agricultural development.

According to Okon E.E. (2009), 'Against the background of enormous challenges and constraints to agricultural development, it is the intention of the government of Nigeria to achieve a fast rate of growth in agricultural production to feed the ever increasing population and to provide employment for about $70 \%$ of the labour force engaged in agriculture, etc. In its statement of agricultural policy (1987), the federal government plans to meet these growing demands through the achievement of the following objectives:

- Self-sufficiency and self-reliance in food production.

- Increased supply of agricultural raw materials to support domestic manufacturing.

- Increased production of cash crops for export, with a view to diversifying away from oil.

- Creation of employment opportunities to absorb some of the increasing labour force.

- Modernization of technologies in food processing, distribution, storage and marketing;

- Integrated development through provision of infrastructural facilities in the rural areas, and

- Protection against environmental degradation.'

Towards achieving the above objectives, several policies which resulted in the establishment of Agricultural development institutions, programmes, projects, agencies and financial institutions were formulated. These includes; Agricultural Research and training institutes, Agricultural Universities, Green Revolution (GR), Operation Feed the Nation (OFN), River Basin Development Authorities, National Economic Empowerment and Development Strategy (NEEDS), Directorate of Food Roads and Rural Infrastructure (DFRR), National Agricultural Land Development Agency (NALDA), Nigeria Agricultural Cooperative and Rural Development Bank (NACRDB), Nigerian Agricultural Insurance Corporation (NAIC) and Agricultural Development Projects (ADP), National Fadama Development Project (NFDP);; National, Special Programme on Food Security (NSPFS); Root And Tuber Expansion Programme (RTEP); Agricultural Transformation Agenda (ATA) among others.

\section{Interaction between Politics and Policy in Agricultural Policy Process}

The earlier discussion on politics/administration dichotomy shows that politics cannot be separated from administration. Politics/administration dichotomy is not relevant today in view of the emerging trend towards the integration of administration and politics. Since policy making is a crucial aspect of administration, it is impossible to divorce politics from policy and its process. Public policy is the heart of government which can be manipulated positively or negatively, depending on the actors involved. These actors are the executive, the legislature, the judiciary, the bureaucrats, the interest groups as well as the politicians, among others. Through these actors, politics interacts with policy. 
Policy process in the agricultural sector is not different from policy processes of other sectors which involve: problem identification, policy demand, agenda setting, policy deliberation and adoption, policy formulation, policy implementation and policy evaluation. In line with Ikelegbe's opinion (1969) which defined public policy as 'An integral programme of actions which an actor (or a group of actors) is accustomed to or intends to undertake in response to given problems or situations with which he is confronted', the important role of actors in policy process cannot be ignored. Actors in policy process make or influence policy and the direction and level of implementation activities. The actors include the legislative bodies (politics), the executive (politics and administration (policy), the judiciary (administration/policy), the bureaucrats (administration/policy), the political parties (politics), expert advisers and citizens. The legislative bodies (who are elected politicians in most cases) are involved in the policy process from the initiation and formulation to implementation, control and review. The legislators are representatives of the citizens and are, therefore, in a position to articulate and aggregate citizens interest and demands by initiating and formulating policy proposals in the legislature. The legislative body enacts the laws, which set up policy programmes and, consequently, determine the content, extent and timing of policies, as well as the personnel, mode and intensity of implementation and source and level of funding (Ikelegbe, 2006). The legislature, of course, is one of the arms of government and, by implication, political since the legislators are elected by the people through political activities. The Executive refers specifically to the chief executive, the cabinet, the political office holders which include Ministers, governors, commissioners, special advisers, assistants, and bureaucrats. The executive possesses enormous influence on the initiation, enactment, implementation, performance and modification of agricultural policy through the powers which they wield as overseers, supervisors, directors, coordinators and managers of administrative agencies and departments of government (Ikelegbe, 2006). This branch of government is actually a major actor in the process of policy as they participate in initiating, drafting and formulating public policies.

The implementation stage of the agricultural policy is where the policy document becomes a reality whereby policies are brought into practice. It is the execution of the law that has been passed. Example is the establishment of a University of Agriculture, the staff (bureaucrats or administrators representing policy in this study) of Ministry of agriculture are involved in setting up the institution, making consultation on infrastructure, employment of staff and enrolment of students in the established institutions.

After articulating and formulating policy proposals, the executive passes the proposals to the legislative bodies. Even after passing the proposals to the legislature, the executive still finds its way around to influence legislators into enacting its favoured policy proposals into law, through what is referred to as 'lobbying'. At the implementation level, the executive is very active in the sense that it is responsible, most of the time, for the provision of all that is necessary to have a successful implementation of policies. These include provision of funds, infrastructures and personnel (bureaucrats who are administrators). This means that if the executive is not particularly interested in a policy, he can deliberately underfund such a policy to ensure that it fails. With the above discussion, there is no doubt that politics (through the legislative body and the executive) inter-relates with policy process.

The Judiciary (administrator hence policy), is the body of judges and courts that interpret the constitution and the laws and is an arm of government that is crucial to the process of policy making. They moderate the actions and the activities of governmental policy actors, in relation to themselves and between themselves on the one hand, and groups and individuals on the other (Ikelegbe, 2006). The judiciary ensures that every governmental action conforms to the intent of the laws. This body is enabled to do this by their possession of the power of judicial review through which they could examine and determine the constitutionality of legislative, executive and bureaucratic actions and policies. It does not formulate nor implement policy but reacts to policy proposals, enactment, implementation and conduct of services and personnel. Such reactions may lay the basis for policy decisions, legitimizing policies and modifying or mortifying them. Another notable thing about the judiciary is that the execution or concretization of judicial policy influence depends on the cooperation of the legislative and executive arms of government. Non-cooperation of the two bodies with the judiciary may result in the policy decisions and changes by the judiciary not being acted upon. The judiciary's intervention is based on cases brought before it by arms of government, institutions, groups and individuals (Ikelegbe, 2006). The judiciary, in spite of the above points raised, still remains an important influence on the policy process as it ensures sanity, propriety, fairness, legality, constitutionality, justice and moderation in the policy process.

The political party is another political actor in policy process. The political party articulates the demands and preferences of the people especially their members and supporters into the political process. The party also uses its resources to ensure that the demands of its supporters are enacted into agricultural policies. For example, in Nigeria, the political party in power may influence the citing of large government farms, agricultural structures or agricultural institutions in its preferred domain.

Political parties, through their members in public office, sometimes wield considerable influence in the execution of public policies particularly when they are in control of the government apparatus. They exercise this influence by ensuring that their manifestoes, policies and their programmes are implemented. Other actors in the policy process include the bureaucracy, interest groups, the citizenry as well as the experts and the professionals. The bureaucracy, who are the civil servants in Ministries of agriculture are located strategically to generate or initiate public policy because it largely possesses the expertise, skills, competence and experience available to government at the formulation and implementation stages. The bureaucrats come in contact regularly with government business and are, therefore, familiar with the needs, problems, aspirations and interests of the citizenry as well as the shortcomings and the inadequacies and the problems of any of the policy of government. These contacts and experiences provide the public officials the challenges and ideas to formulate new policy responses. For example, the distribution of fertilizers and other agricultural incentives to farmers are largely handled by the bureaucrats (agricultural extension workers). 
Another set of actors are the interest groups such as the Farmers association as well as Non-Governmental Organizations (NGOs). These groups exist principally to project, pursue and protect common interests. Their influence on the agricultural policy process occurs at every stage. The interest groups sometimes initiate policy through suggestion and recommendation of policy solutions to problems that pertain to their interests. The citizenry is the main actor of policy process due to many reasons, namely: it constitutes the human environment of policies. Similarly, Ikelegbe (2006) posits that 'the human environment's perceptions, values, preferences and demands constitute the major environmental influence on public policy'. The citizens make demands for public policy through protests, public outcry etc.; they contribute the resources for the formulation and execution of policies through payment of tax and other levies; and finally, they have the power of electing, supporting or rejecting governmental actors and the policies they stand for. The citizens influence the policy process through their political parties, interest groups, elections and the mass media. Citizens also constitute the experts and professionals who are consulted by government for policy advice and related inputs. Since the problems confronting government increase enormously by the day the services of experts and professionals become necessary. For example, the problem with dwindle level of professional agricultural scientists in Nigeria to boost the training of agricultural personnel (extension workers) who will in turn train the local farmers on how to improve their crops attracted inputs from professionals who advised that higher agricultural institutions be established mainly for this purpose. This led to the establishments of Universities of Agriculture offering BSC, MSc and PhD programmes in agricultural science. The involvement of experts and professionals is advantageous because the advice emanating from them is considered to be free from internal limitations, values and politics.

At the stage of recognizing that there is a problem to be solved, it is the people - the citizens, a group of people, the bureaucrats, the legislative body, or, even the executive that will come up with policy demands. From the level of problem recognition to that of policy adoption, a lot of politics is involved. When the demands are made on the government on certain issues, if it is not translated into political issue, it may not get to be on the agenda. The agenda stage is where stage where government contemplate over the demands from the environment. This is always a political process in which groups struggle for power to be in control. It is also at this level that ideological and interest groups compete to broaden the agenda or include their issues or to narrow it by excluding issues that they do not want considered (Cochran, et al, 2003). After the adoption of policies, the implementation stage is very crucial and it involves a lot of politics. Remember, there is no way a policy can be implemented successfully without adequate funding and availability of personnel. Allocation of funds, infrastructures, as well as provision of personnel is political. If the government is not in favour of the policy, it is capable of frustrating it by failing to provide adequately for its implementation. When one considers the contributions of each of the actors discussed above the legislature, the executive, the judiciary, the political party, even the citizens and the interest groups politics will be found at every stage of the policy process from the problem recognition to the policy evaluation.

\section{Conclusion}

This study tried to show the relationship between politics and policy through the policy process of agricultural sector in Nigeria. This study examined the different definitions of politics and policy/public policy expressing the importance of one to the other. The discussion on politics/administration dichotomy also brought out the fact that politics cannot be separated from administration and, by implication, from policy which is an aspect of administration. The various actors and their contributions to policy process in agricultural sector of Nigeria have been used to show the way and manner that politics is an indispensable part of policy process. This paper, therefore, concludes that there is always interaction between politics and public policy at every stage of policy process, resulting in a close relationship which makes it rather difficult to divorce one from the other.

\section{References}

i. Adamolekun, L. (1983). Public Administration: A Nigerian and Comparative Perspective. New York: Longman.

ii. Anderson, J. E. (1975). Public Policy Making. New York: Praeger.

iii. Awopeju, A. (2010). The Effects of Politics on Government and Development in Nigeria. In Femi Omotoso, A.A, Agagu and Ola Abegunde (eds) Governance, Politics and Policies in Nigeria: An Essay in Honour of Prof. Dipo Kolawole, Porto Nove: Editions -124.

iv. Cochran, C. E., Mayer, L.C., Carr, T. R., \& Cayer, N.J. (2003). American Public Policy: An Introduction, 7 th Edition. Wadsworth: Thomson Learning.

v. Dye, T. (1975). Understanding Public Policy, 2nd Ed., New Jersey: Prentice Hall.

vi. Easton, D. (1965). A Systems Analysis of Political Life, New York: John Wiley \& Sons Inc.

vii. Eyestone, R. (1971). The Threads of Public Policy: A Study in Policy Leadership, Indianapolis: Bobbs-Merrill.

viii. Goodnow, F. J. (1900). Politics and Administration, New York: The Macmillan Company.

ix. Guy, B.P, (1984). The politics of bureaucracy. $2^{\text {nd }}$ edition. New York: Longman Inc.

x. Igho, O. N. (2006). Governance and Politics in Nigeria. A Lecture delivered on November 21, 2006 at the Staff and Graduate Seminar, Department of Political Science and Public Administration, University of Benin, Benin, Edo State of Nigeria.

xi. $\quad$ Ikelegbe, A.O. (1969). Public Policy-Making and Analysis. Benin City: Uri publishing Limited.

xii. Ikelegbe, A.O. (2006).Public Policy Analysis: Concepts, Issues and Cases, Lagos: Imprint Services.

xiii. Khan, H. (1997). Public Administration: An Introduction, Kendal: Hunt Publisher.

xiv. $\quad$ Kolawole, D. (1997). Readings in Political Science. Ibadan: Daakal Publisher.

xv. Lasswell, D (1936). Politics: Who Gets What, When How? Stanford, California: Stanford University Press 
xvi. Lasswell, D. and Kaplan, A. (1950). Power and Society, New Haven: Yale University Press.

xvii. Lepawsky A. (1970). Administration: The Art and Science of Organization and Management. New Delhi, India: Oxford and IBM Publishing Co.

xviii. Mohd. A.A.K. (1983). Politics and administration in a welfare state, in public administration in India - Emerging Trends: edited by S.I. Kaushik and Pradeep Sahni; Kitab Mahal, Allahabad.

xix. Okon, E.E. (2009). Public Policy Analysis and Decision Making. Lagos: Concept Publications.

xx. Polinaidu, S. (2004). Public Administration. New Delhi: Galgotia Publications PVT Ltd.

xxi. $\quad$ Robinson, J. A. \& Majak, R. R., (1967). The Theory of Decision Making.In James C. Charlesworks (ed) Contemporary Political Analysis, New York: Free Press.

xxii. Woodrow Wilson. (1941). The study of public administration', political Science Quarterly, vol. 2, pp. 197-222. (Reprint). Quoted in Basic issues in public administration; edited by Rowart Donald, New York; 1981 